\title{
Analisa Pengaruh Posisi Sinyal Terhadap Sudut Datang Arah Angin pada Generator Windbelt Terhadap Performa Daya Output
}

\author{
Zaenal Abidin, Sardono Sarwito , Eddy Setyo K. \\ Jurusan Teknik Sistem Perkapalan, Fakultas Teknologi Kelautan, Institut Teknologi Sepuluh Nopember \\ Jl. Arief Rahman Hakim, Surabaya 60111 Indonesia \\ e-mail: sarsan@ne.its.ac.id
}

\begin{abstract}
Abstrak-Windbelt merupakan alat konversi energi angin menjadi listrik selain turbin dan kincir angin. Dibandingkan dengan turbin dan kincir angin windbelt sangat murah dan tidak memerlukan area yang luas dalam instalasinya. serta tidak menimbulkan kebisingan seperti turbin dan kincir angin. Terobosan desain alat konversi energi angin ini masih terbilang baru, sehingga perlu untuk dikembangkan dan diadakan penelitian lebih lanjut untuk mendapatkan efisiensi yang tinggi. Karena dibandingkan dengan turbin dan kincir angin, windbelt memiliki efisiensi yang sangat kecil sehingga hanya digunakan untuk pembangkit skala kecil. Maka dalam penulisan tugas akhir ini akan dibahas mengenai kajian yang fokus pada analisa pengaruh posisi windbelt terhadap sudut datang arah angin dengan melakukan percobaan variasi sudut datang arah angin dari posisi $0^{\circ}$ sampai $90^{\circ}$ dengan beda $5^{\circ}$. Dalam percobaannya digunakan sebuah blower yang berkecepatan angin rata-rata $10,3 \mathrm{~m} / \mathrm{s}$. Dari percobaan ini didapatkan sudut terbaik pada $75^{\circ}$ dengan hasil tegangan dan arus rata-rata sebesar 2,9 volt dan $0,05 \mathrm{~A}$.
\end{abstract}

Kata Kunci-Windbelt, Sudut datang Angin, Daya Output.

\section{Pendahuluan}

$\mathrm{D}$ ewasa ini banyak dilakukan penelitian mengenai energi alternatif yang terbarukan dan juga ramah lingkungan. Sumber energi tersebut berasal dari panas bumi, sinar matahari, angin, air dan sebagainya. Teknologi ini timbul karena adanya kecemasan terhadap energi fosil yang diprediksi akan habis di masa mendatang. Disamping itu juga energi fosil menyumbangkan polusi udara terbesar yang berakibat pada pemanasan

Upaya untuk mengubah energi alternatif ini membutuhkan alat konversi. Alat konversi merupakan sebuah alat yang digunakan untuk mengubah energi dari bentuk satu kedalam bentuk yang lain. Alat konversi memiliki bentuk yang berbeda-beda bergantung pada bentuk energi yang akan dikonversi. Untuk konversi energi radiasi matahari menjadi listrik dibutuhkan panel surya, energi potensial air diubah menjadi listrik dengan menggunakan turbin air dan turbin angin untuk mengkonversikan energi kinetik angin menjadi listrik. Sebagian besar energi yang dikonversikan diubah kedalam energi listrik, karena mudah untuk diubah kedalam bentuk energi lain dan juga dapat disimpan.

Dalam mendesain alat konversi energi terdapat banyak model yang telah ditemukan, terutama untuk konversi energi angin, diantaranya adalah kincir angin, turbin angin, dan windbelt generator yang baru-baru ini telah ditemukan. Generator windbelt merupakan terobosan desain alat konversi yang terbaru, alat ini ditemukan oleh Shawn Frayn, seorang lulusan dari MIT. Generator windbelt dinyatakan lebih efesien hingga 30 kali dibandingkan turbin angin berukuran kecil (wikipedia).

Untuk penelitian terhadap alat ini, belum banyak orang yang melakukan. Sehingga perlu diadakannya studi penelitian untuk lebih lanjut. Oleh karena itu, munculah ide untuk membuat analisa posisi windbelt terhadap sudut datang arah angin terhadap kinerja dari generator windbelt dalam menghasilkan energi listrik.

\section{Metodologi Penelitian}

Metodologi penelitian adalah kerangka dasar dari tahapan penyelesaian skripsi. Metodologi tersebut mencakup semua kegiatan yang akan dilaksanakan untuk memecahkan masalah atau melakukan proses analisa terhadap permasalahan dalam skripsi. Selama pengerjaan skripsi ini, penulis membagi pengerjaannya dalam beberapa tahapan pengerjaan. Tahapan pengerjaan skripsi ini antara lain:

\section{A. Identifikasi Masalah}

Dalam identifikasi masalah yang dibahas dalam skripsi ini adalah analisa posisi generator windbelt terhadap sudut arah datang angin untuk mendapatkan daya yang optimal dalam aplikasinya.

\section{B. Studi Literatur}

Sebelum dilakukan penelitian, dilakukan studi mengenai beberapa literatur dan referensi yang berkaitan dengan generator windbelt. Studi literatur ini bertujuan untuk memperoleh teori-teori dasar yang digunakan, hasil penelitian dan informasi yang berkaitan dengan generator windbelt yang akan dianalisa dalam skripsi ini. Studi literatur dilakukan dengan pengkajian berupa jurnal, buku, paper, dan web, atau media lain yang menunjang penulisan skripsi ini.

\section{Pengumpulan Data}

Pengumpulan data dilaksanakan sebagai acuan dalam pengerjaan skripsi ini. Data-data yang dikumpulkan harus dapat menunjang dalam penyelesaian permasalahan yang ada. Data - data yang diperlukan dalam penyelesaian masalah dibagi dalam dua bagian, yaitu data tetap dan data variasi. Data tetap merupakan data yang dibutuhkan untuk pengujian yang sifatnya tetap atau tidak dapat diganti selama pengujian, yaitu : kecepatan angin dan dimensi alat. Dan data variasi merupakan data yang dibutukan dalam pengujian yang 
berubah sewaktu pengujian dengan jangkauan tertentu, yaitu sudut datang arah angin. Data-data ini akan digunakan untuk menguji alat, sehingga didapatkan hasil keluaran yang diinginkan.

\section{Pembuatan Alat}

Pada tahap ini dilakukan pembuatan alat yang akan digunakan dalam pengujian. Dalam pembuatan alat ini diperlukan data dimensi dari windbelt, data tersebut diperoleh dari jurnal IJEIT, ISSN:2277-3754. [5] Pemilihan dimensi dari jurnal ini, karena desain tersebut telah berhasil diuji dan dapat bekerja dengan baik. Dari data tersebut dibuat desain yang menyerupai bentuk desain sebelumnya, namun terdapat beberapa perubahan seiring dalam proses pembuatannya, yaitu diameter dalam dan luar koil, dimensi magnet, dimensi pita dan terdapat bantalan koil yang digunakan untuk memposisikan koil pada magnet. Perubahan itu terjadi karena kesalahan proses pembuatan, dan dimensi magnet yang ada di pasaran tidak ada yang sesuai dengan jurnal serta mutlak untuk meminimalkan kegagalan pada saat pengujian.

\section{E. Percobaan Alat}

Pada tahap ini dilakukan pengujian alat yang dilakukan di laboratorium mesin kapal. Dalam pengujian ini diperlukan sebuah blower yang digunakan sebagai sumber angin buatan. Kecepatan angin yang dihasilkan blower tidak dapat diubah sehingga dibuat tetap. Kemudian dibuat sebuah tunnel angin yang diletakan pada sisi keluaran angin pada blower yang berguna untuk memusatkan angin pada windbelt. Pengujian dilakukan pada jarak $110 \mathrm{~cm}$ dari depan blower. Pada saat pengujian dilakukan pengukuran arus dan tegangan, serta dilakukan pengubahan posisi sudut datang angin dengan mengubah posisi windbelt. Sudut datang arah angin divariasikan dari 0 derajat sampai 90 derajat dengan kelipatan 5 derajat, yaitu $0,5,10,15, \ldots, 90$.

\section{F. Analisa Data dan Pembahasan}

Pada tahap ini dilakukan analisa dan pembahasan terkait dari hasil pengujian alat. Yang nantinya akan menjadi hasil dari tujuan penelitian ini.

\section{G. Kesimpulan dan Saran}

Pada akhir pengerjaan skripsi ini akan ditarik kesimpulan dari beberapa pengujian yang telah dilakukan. Kesimpulan yang didapatkan merupakan jawaban dari permasalahan yang dibahas dalam penelitian ini dan juga merupakan rangkuman dari serangkaian proses penelitian yang dilakukan. Disamping itu juga akan diberikan saran-saran mengenai penelitian ini. Dimana saran-saran tersebut mungkin nantinya akan berguna dalam perkembangan penelitian selanjutnya, maupun sebagai bantuan solusi terhadap permasalahan yang ada.

\section{HASIL DAN PEMBAHASAN}

Data yang yang didapatkan dari variasi sudut arah datang angin berupa tegangan dan arus yang dihasilkan oleh generator. Kemudian data lain berupa kecepatan angin merupakan data masukan yang didapat dari kecepatan angin yang dihasilkan oleh blower. Data kecepatan angin didapatkan dengan melakukan pengukuran menggunakan anemometer analog didepan blower dengan jarak $110 \mathrm{~cm}$ sesuai dengan jarak pada percobaan alat. Dan data yang didapatkan pada saat pengukuran adalah sebagai berikut

TABEL 4.1 KeCEPATAN ANGIN

\begin{tabular}{cc}
\hline \hline Pengambilan ke- & Kecepatan Angin $(\mathbf{m} / \mathbf{s})$ \\
\hline 1 & 10 \\
2 & 10 \\
3 & 10.2 \\
4 & 10 \\
5 & 10.2 \\
6 & 10.2 \\
7 & 10 \\
8 & 10.9 \\
9 & 11 \\
10 & 10.5 \\
Rata-rata & 10.3 \\
\hline \hline
\end{tabular}

\section{A. Pembuatan Prototype Generator Windbelt}

Untuk melakukan penelitian pengaruh sudut datang arah angin terhadap performa daya output dari generator windbelt, maka nantinya akan dibuat sebuat prototype yang akan diuji coba dengan kondisi yang disesuaikan. Prototype ini akan bekerja pada sudut yang bervariasi dari sudut 0 derajat sampai 90 derajat.

Dimensi perancangan genrator windbelt didasarkan pada jurnal IJEIT, ISSN:2277-3754.[5] Desain yang akan dibuat prototype memiliki dimensi sebagai berikut:

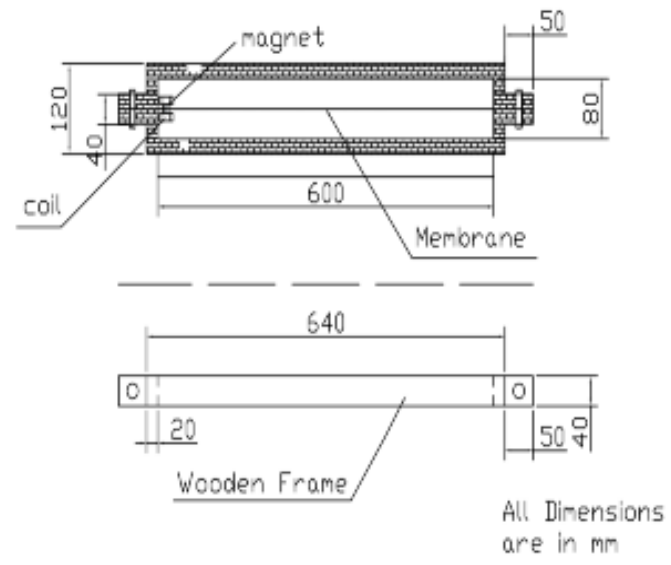

Gambar 2.1 Dimensi Frame dan Belt Windbelt

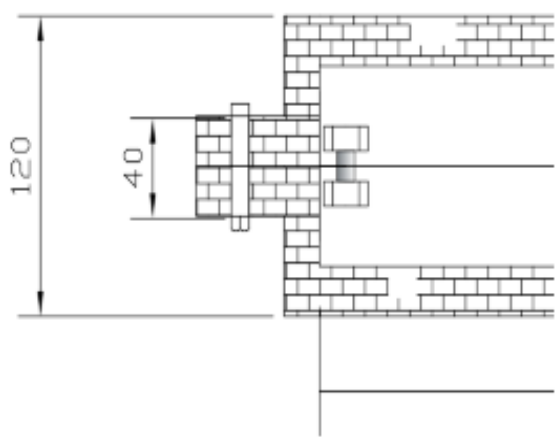

Gambar 2.2 Perancangan Letak Koil dan Magnet Generator Windbelt 


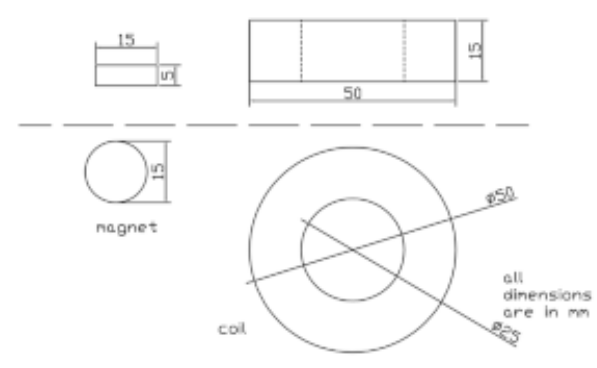

Gambar 2.3 Dimensi Magnet dan Koil

\section{B. Percobaan Prototype dan Pengambilan data}

Untuk menguji performa generator windbelt dilakukan percobaan kerja alat secara real. Percobaan ini akan dilakukan pengukuran tegangan dan arus pada keluaran generator. Dalam percobaan ini, peletakan koil dan magnet berada ditengah-tengan pita dan dipasang secara horizontal didepan blower dengan jarak 1,1 meter. Kecepatan angin yang mengalir dari blower rata-rata $10,8 \mathrm{~m} / \mathrm{s}$ yang sebelumnya telah diukur dengan anemometer.

Sedangkan yang berbeda dari setiap percobaan adalah sudut arah datang angin yang divariasikan dari 0 derajat sampai 90 derajat dengan kelipatan 5 derajat, yaitu 0, 5, $10,15, \ldots, 90$. Sehingga nantinya akan dilakukan percobaan sebanyak 18 kali. Pada setiap percobaan akan dilakukan selama 1 jam dan mencatat nilai tegangan dan arus yang dihasilkan oleh generator setiap 1 menit. Hasil dari percobaan yang telah dilakukan dapat dilihat pada penyajian grafik dibawah ini:

\section{Grafik Tegangan VS Derajat Sudut Face terhadap Arah Angin}

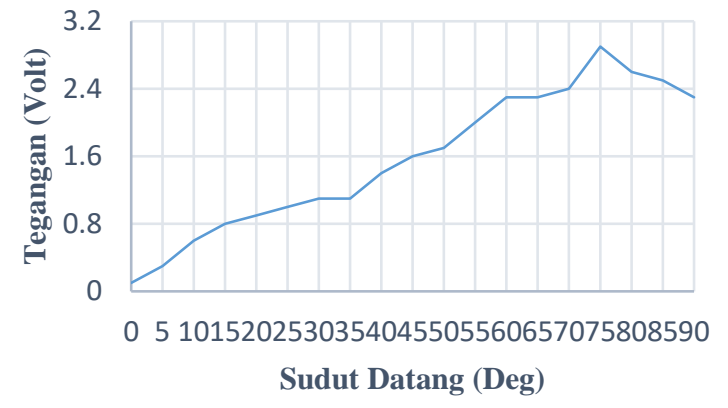

Grafik 3.1. Perbandingan antara sudut datang arah angin dengan tegangan yang dihasilkan wind belt

\section{Grafik Arus VS Derajat sudut Face Terhadap arah angin}

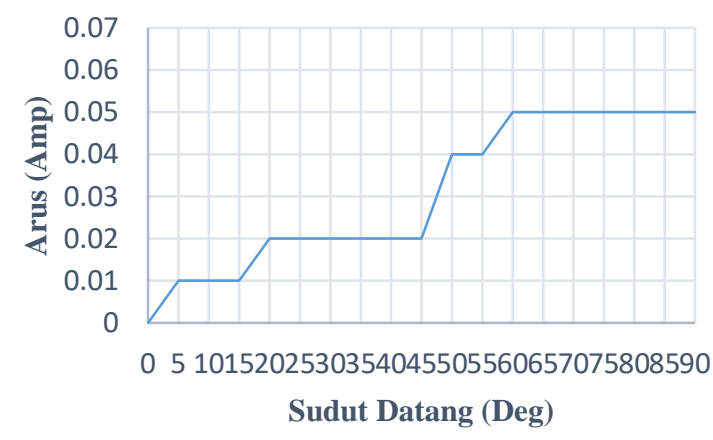

Grafik 3.2. Perbandingan antara sudut datang arah angin dengan arus yang dihasilkan wind belt

\section{Perhitungan Daya Wind Belt}

Daya wind belt dihitung berdasarkan rumus :

$P=V . I \quad$ (watt)

Hasil perhitungan daya windbelt yaitu seperti tampak pada Grafik dibawah ini.

\section{Grafik Power Output VS Derajat sudut Face Terhadap arah angin}

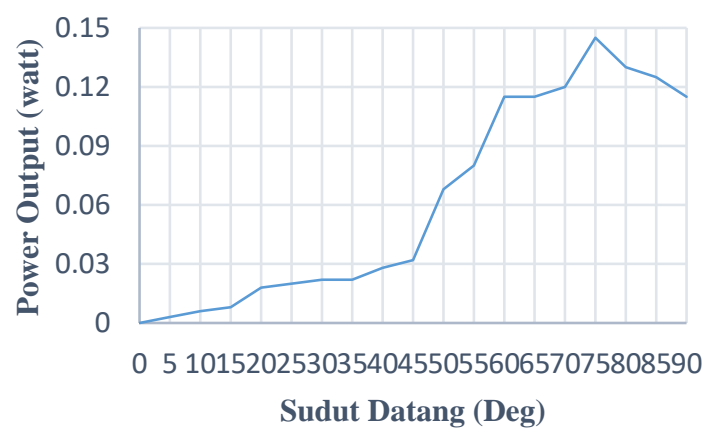

Grafik 3.3. Perbandingan antara sudut datang arah angin dengan power output yang dihasilkan wind belt

Daya listrik yang dihasilkan wind belt bertambah seiring dengan besarnya sudut datang terhadap posisi wind belt. Besarnya sudut menandakan besarnya aliran massa udara yang diterima bidang muka (face) wind belt untuk kemudian dikonversikan menjadi gerakan aeroelastic flutter yang menggerakan magnet keluar masuk kumparan dan selanjutnya akan diubah menjadi gaya gerak listrik yang memicu aliran arus listrik.

Pada grafik diatas daya yang terbesar adalah pada sudut datang $75^{\circ}$ yaitu sebesar 0,145 watt atau sekitar 145 miliwatt. Secara teori seharusnya sudut datang $90^{\circ}$ menghasilkan daya yang lebih besar dibandingkan pada sudut datang $75^{\circ}$. Karena bilamana luas bidang yang diterpa angin semakin besar maka akan menimbulkan gerakan osilasi yang besar pula. Hal ini dikarenakan pada sudut $75^{\circ}$ memungkinkan gerakan osilasi pita untuk mengangkat magnet sehingga menggerakan magnet keluar masuk kumparan sehingga menghasilkan daya yang besar.

\section{Perhitungan Daya Angin}

Daya angin dengan kecepatan $10,3 \mathrm{~m} / \mathrm{s}$ yang menerpa pita dengan dimesi panjang $600 \mathrm{~mm}$ dan lebar $20 \mathrm{~mm}$, yaitu:

$$
\begin{aligned}
& P=\frac{1}{2} \rho v^{3} \mathrm{~A} \\
& P=\frac{1}{2} \times 1,2 \mathrm{kgm}^{-3} \times\left(10,3 \mathrm{~ms}^{-1}\right)^{3} \times(0,6 \mathrm{~m} \times 0,02 \mathrm{~m}) \\
& P=\frac{1}{2} \times 1,2 \mathrm{kgm}^{-3} \times 1092,727 \mathrm{~ms}^{-1} \times 0,012 \mathrm{~m}^{2} \\
& P=7,86 \mathrm{watt}
\end{aligned}
$$

Daya angin sesungguhnya kira-kira $1 / 2$ dari nilai daya diatas, sebab diameter kincir angin hanya $40 \mathrm{~cm}$. [3] maka daya angin yang menerpa pita adalah kira-kira 3,6 watt. Sehingga perhitungan efisiensinya adalah :

$$
\eta=\frac{\text { Daya listrik }}{\text { Daya angin }}=\frac{145 \mathrm{~mW}}{7200 \mathrm{~mW}} \times 100 \%=1,84 \%
$$

Nilai efisiensi ini termasuk sangat rendah, karena sebagian besar energi angin belum seluruhnya dikonversikan menjadi energi listrik. Untuk memaksimalkannya perlu ditambahkan kumparan pada bagian sisi atas. Karena pada percobaan hanya dipakai satu kumparan saja. Dan untuk mendapatkan daya lebih 
besar lagi bisa ditambahkan dua kumparan lagi pada ujung sisi lainnya.

\section{KESIMPULAN DAN SARAN}

\section{A. Kesimpulan}

Setelah melakukan percobaan dan pengamatan maka dapat diambil beberapa kesimpulan yaitu :

- Sudut datang arah angin mempengaruhi daya yang dihasilkan oleh windbelt

- Daya terbesar yang dihasilkan pada percobaan ini adalah pada sudut $75^{\circ}$ yaitu sebesar 145 miliwatt

- Daya yang dihasilkan masih terlalu kecil untuk dipakai dalam skala besar.

- Performa wind belt masih kurang maksimal meskipun didapatkan sudut datang yang baik dalam mengkonversikan energi angin menjadi listrik.

\section{B. Saran}

- Sebaiknya dilakukan percobaan dengan lebar pita yang berbeda untuk mengetahui apakah pada sudut $75^{0}$ wind belt tetap menghasilkan daya terbesar.

- Pemilihan material pita yang baik untuk bisa menggerakan magnet

- Diperlukan percobaan yang sama dengan posisi wind belt secara vertikal.

\section{UCAPAN TERIMA KASIH}

Penulis mengucapkan terimakasih kepada Bapak Sardono Sarwito dan Bapak Eddy Setyo yang membimbing dalam penelitian ini, serta asisten laboratorium yang telah banyak membantu.

\section{DAFTAR PUSTAKA}

[1] Hanin, wildan. "Perancangan Turbin Angin Sebagai Bagian dari Sistem Pembangkit Listrik di Kapal".2008.Teknik Sistem Perkapalan.ITS Surabaya.

[2] Bagaskara, Surya. “Analisa Pemanfaatan Turbin Angin Sebagai Penghasil Energi Listrik Alternative di Pulau Panggang Kepulauan Seribu".2011.Teknik Sistem Perkapalan.ITS Surabaya.

[3] Ihda, Arif Prasetya. "Perencanaan Kincir Angin Sebagai Pengisi Baterai pada Kapal Ikan 5 GT Berpenggerak Motor DC'.2008.Teknik Sistem Perkapalan.ITS Surabaya.

[4] Wiley, John, 2008, "Wind Power in Power System".British Library, England.

[5] Dr.P.Balaguru, B.Vignesh Raj, B.E.Vignesh.2008.Low Cost Energy Production Using Wind Belt Technology.International Journal of Engineering and Innovative Technology, ISSN:22773754 